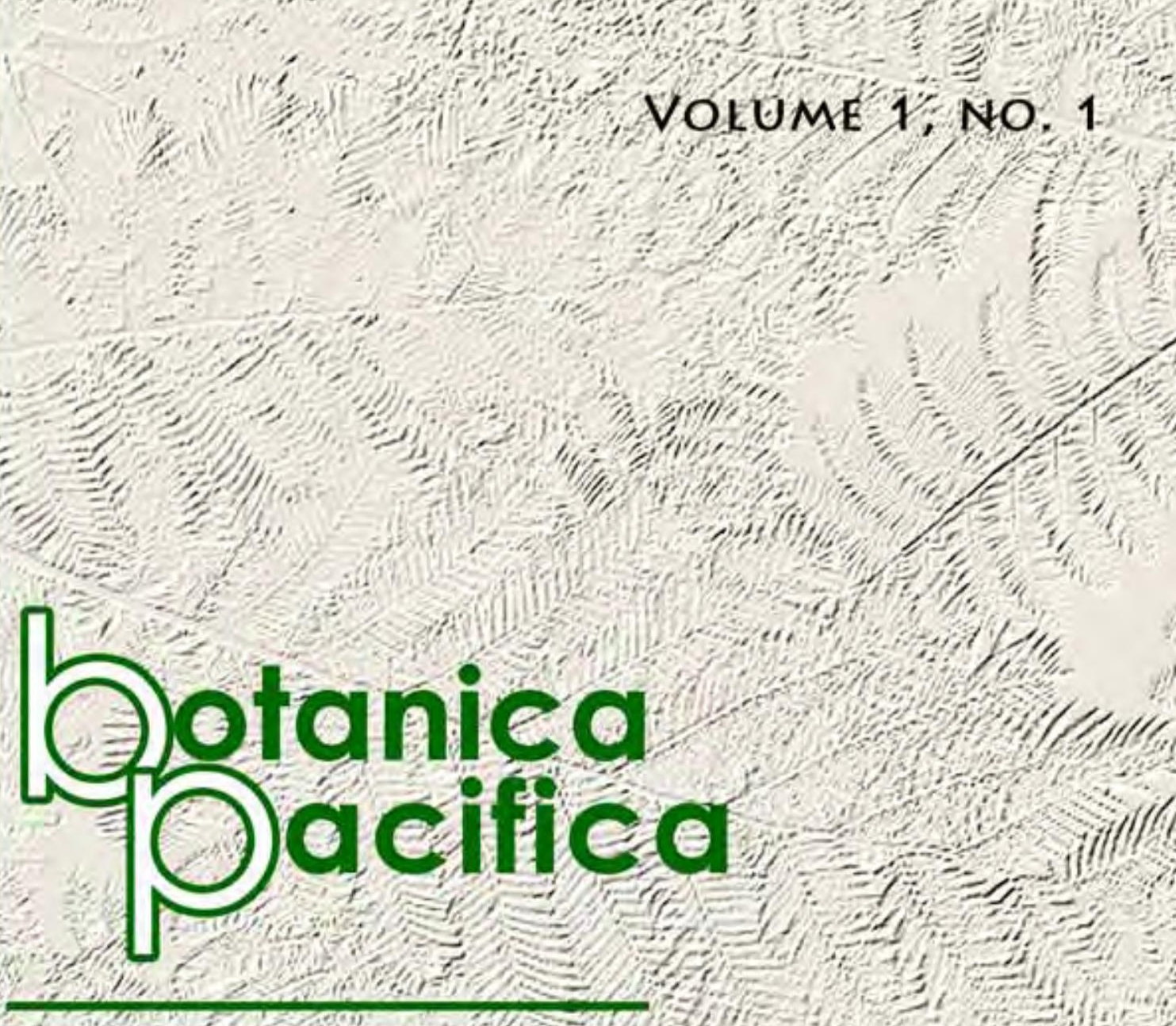

A journal of plant SCIENCE AND CONSERVATION

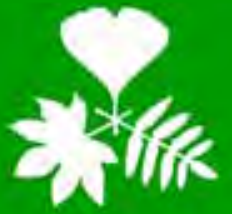

BOTANICAL GARDEN-INSTITUTE FEB RAS

*

INSTITUTE OF BIOLOGY AND

SOIL SCIENCE FEB RAS

WWW.CEOBOTANICA.RU/BP

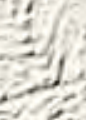

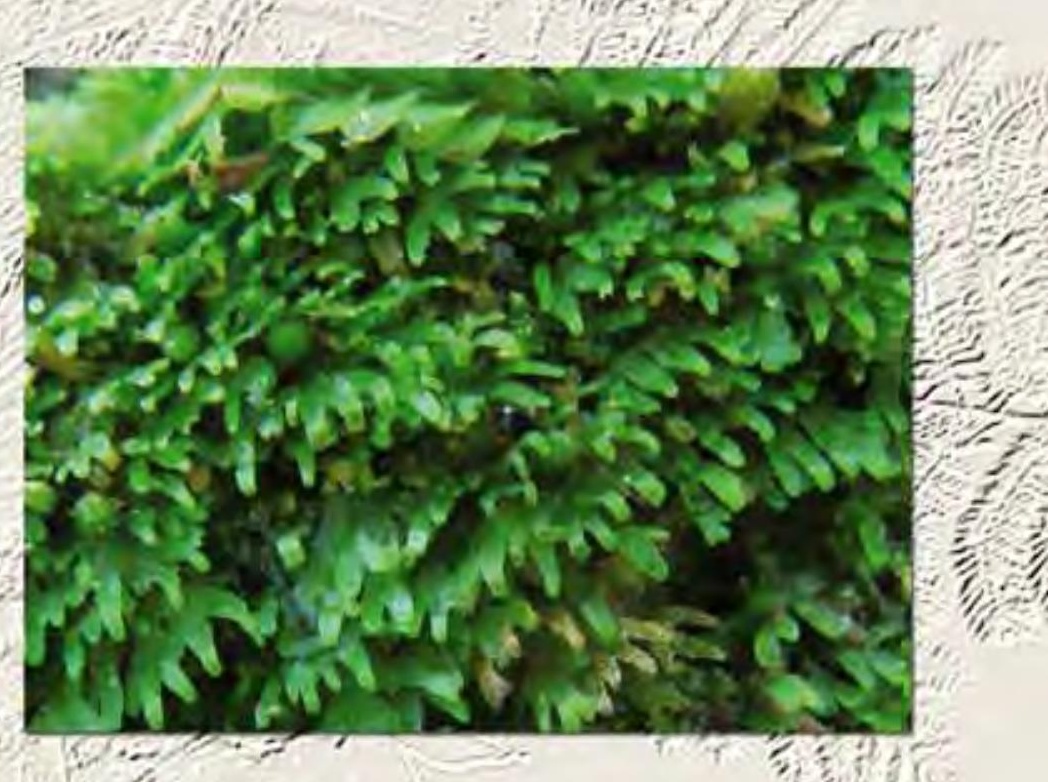




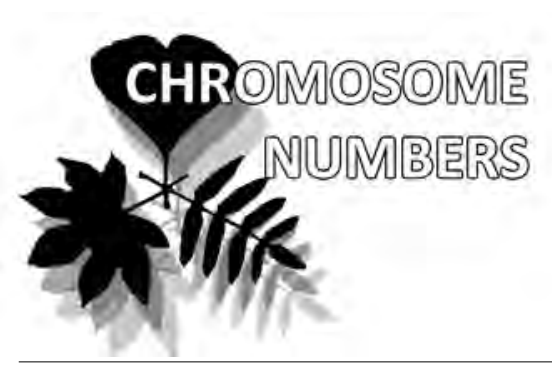

Victor V. Chepinoga

Department of Botany

Irkutsk State University

Irkutsk 664003 Russia

2 Albrecht von Hallier Institute of Plant Sciences

Georg-August University of Göttingen Göttingen 37073 Germany

E-mail: Victor.Chepinoga@gmail.com

Aleksandr A. Gnutikov

V. L. Komarov Botanical Institute RAS

St.-Petersburg 197376 Russia

Pavel I. Lubogoschinsky

1 Department of Botany

Irkutsk State University

Irkutsk 664003 Russia

* Corresponding author

Manuscript received: 21.02.2012

Review completed: 12.04.2012

Accepted for publication: 15.07.2012

\section{Chromosome Numbers of Some Vascular Plant Species from the South Baikal Siberia}

\author{
Victor V. ChePINOGA ${ }^{1,2^{*}}$, Aleksandr A. GNUTIKOV ${ }^{3} \&$ Pavel I. LubOGOSCHINSKY $^{1}$
}

\begin{abstract}
A B S T R A C T
Chromosome numbers for 22 vascular plant species from Baikal Siberia are reported. The four species (Asparagus brachyphyllus Turcz., Lupinaster popovii Roskov, Primula serrata Georgi, Galium paradoxum Maxim.) are studied caryologically for the first time. Also the new cytotypes in Asparagus davuricus Fisch. ex Link and Myriophyllum verticillatum L. were revealed. For 7 species there are first chromosome counts in Siberia.
\end{abstract}

Keywords:

chromosome numbers, vascular plants, flora, Baikal region, South Siberia, Russia

Чепинога В. В., Гнутиков А. А., Аюбогощинский П. И. Хромосомные числа некоторых видов сосудистых растений из Байкальской Сибири

Приводятся хромосомные числа Аля 22 видов сосудистых растений с территории Байкальской Сибири. Четыре виАа (Asparagus brachyphyllus Turcz., Lupinaster popovii Roskov, Primula serrata Georgi, Galium paradoxum Maxim.) исследованы впервые. Новые кариологические расы обнаружены у Asparagus davuricus Fisch. ex Link, Myriophyllum verticillatum L. Аیя семи видов впервые хромосомные числа получены на материале с территории Сибири.

Ключевые слова:

числа хромосом, сосудистые растения, флора, Байкальский регион, Южная Сибирь, Россия
This paper continues a series of our contributions to chromosome numbers study on plant species from the Baikal Siberia (Chepinoga et al. 2008, 2009, 2010a, 2010b, Probatova et al. 2008a, 2008c, etc.). Plants for this study were mostly collected in the south of Zabaikalskii Krai (former Chitinskaya Oblast'), including Aginskii, Borzinskii, Mogoituyskii, Ononskii, Soloviovskii, Uletovskii Raions (districts). Some plants were collected in southern part of Republic of Buryatia (Kabanskii, Mukhorshibirskii Raions) and Irkutskaya Oblast' (Shelekhovskii, Sludyanskii Raions, Irkutsk city).

An asterisk $\left(^{*}\right)$ before the species name indicates the first chromosome count for the species, and before chromosome number - a new cytotype. Chromosome counting was made by A. A. Gnutikov. Vouchers are deposited in IRKU; duplicate samples are in VLA.

\section{A C E R A CEA E}

Acer negundo L., 2n $=26$.

IRKU C089, Russia, Irkutskaya Oblast', downtown of Irkutsk city, Kirov square, $52^{\circ} 17^{\prime} \mathrm{N}, 104^{\circ} 16^{\prime} \mathrm{E}, 22 . \mathrm{VI} .2005$, coll. A. Chepinoga \& B. Batbayar.

The diploid chromosome number $2 \mathrm{n}=26$ is constant within the species (see Index ..., 1981, 1985, 1990, 1991, 1998, 2000). First count in Siberia.

\section{A L L I A C E A E}

Allium microdictyon Prokh., 2n = 16.

IRKU C1034, Russia, Republic of Buryatia, Kabanskii Raion, Khamar-Daban Range, $2 \mathrm{~km} \mathrm{~S}$ of Baikal Lake, lower course of the Pereyemnaya River, riverbank, $453 \mathrm{~m}$ alt., $51^{\circ} 33^{\prime} \mathrm{N}$, $105^{\circ} 10^{\prime} \mathrm{E}, 07 . \mathrm{VII} .2009$, coll. R. Moriz.

The species has been repeatedly investigated karyologically; data from the Baikal Siberia are also available (Krogulevich 1976, 1978, Belaeva \& Siplivinsky 1981, Friesen 1985, 1991, Chepinoga et al. 2010b). The chromosome number is constant.

\section{Allium neriniflorum G. Don ex Loudon (Caloscordum neriniflorum Herb.), 2n = 16.}

IRKU C737, Russia, Zabaikalskii Krai, Aginskii Raion, 4 km W of Gunei village, left riverside of the Onon River, lakeside of oxbow lake Stepnoe, in grassland steppe, $652 \mathrm{~m}$ alt., $50^{\circ} 30^{\prime} \mathrm{N}, 114^{\circ} 29^{\prime} \mathrm{E}$, 17.VII.2008, coll. P. Lubogoschinsky.

A. neriniflorum, an East Asian species, occurs in Russia in Zabaikalskii Krai only. Outside Russia it is distributed in Eastern Mongolia and North-Eastern provinces of China. Diploid, with apparently constant chromosome number $2 \mathrm{n}=16$ (Friesen, 1986; see Index..., 2000, 2006). The tetraploid chromosome number $2 \mathrm{n}=32$, reported from Shanxi, China (Znang 1994) evidently belongs to another species. Noteworthy, Xu \& Kamelin (2000) have not reported $A$. neriniflorum from Shanxi, and they indicated only $2 \mathrm{n}=$ 16 for this species. 
Allium polyrhizum Turcz. ex Regel, 2n = 32 .

IRKU C760, Russia, Zabaikalskii Krai, Borzinskii Raion, 15 $\mathrm{km}$ S of Kulussutai village, between Zun-Torei and Barun-Torei lakes, feather grass steppe, $601 \mathrm{~m}$ alt., $50^{\circ} 06^{\prime} \mathrm{N}, 115^{\circ} 41^{\prime} \mathrm{E}$, 28.VII.2008, coll. P. Lubogoschinsky. First count in Siberia.

This species has been investigated karyologically from China only. Two counts $(2 \mathrm{n}=32)$ were made from the North-East China, territories neighboring to Zabaikalskii Krai (Toglor et al. 1993, Yang et al. 1998). In contrast, diploid number $2 \mathrm{n}=16$ was reported from Tibetan Plateau (Hongguan et al. 2005); however, this count may belong to some other species.

\section{Allium ramosum L., 2n = 16 .}

IRKU C609, Russia, Zabaikalskii Krai: Uletovskii Raion, 5 km SW of Cheremkhovo village, left riverside of the Ingoda River, steppe, $51^{\circ} 28^{\prime} \mathrm{N}, 112^{\circ} 43^{\prime} \mathrm{E}, 10 . \mathrm{VIII} .2007$, coll. A. Gnutikov \& I. Enushchenko; IRKU C877, C879, Aginskii Raion, 28 km NW of Nizhnii Zassuchey village, saline lake Kunkur, feather grass steppe, $636 \mathrm{~m}$ alt., $50^{\circ} 42^{\prime} \mathrm{N}, 114^{\circ} 53^{\prime} \mathrm{E}, 21$.VII.2008, coll. M. Isaikina.

\section{$-2 \mathrm{n}=32$}

IRKU C762, Russia, Zabaikalskii Krai, Borzinskii Raion, 15 $\mathrm{km} \mathrm{S}$ of Kulussutai village, between Zun-Torei and Barun-Torei lakes, feather grass steppe, $601 \mathrm{~m}$ alt., $50^{\circ} 06^{\prime} \mathrm{N}, 115^{\circ} 41^{\prime} \mathrm{E}$, 28.VII.2008, coll. P. Lubogoschinsky.

Two karyological races are known for this Asian forest-steppe species: di- and tetraploid $(x=8 ; 2 n=16$ and 32). Diploids were reported from China only (Index... 1988, 1998, 2000, 2006, 2010). The origin of some diploid specimens is unknown (see Agapova et al. 1990). Chromosome numbers for $A$. ramosum were repeatedly counted in plants from different regions of South Siberia and the Russian Far East (Primorskii Krai), but all of them were $2 n=32$ (Sokolovskaya 1966, Rostovtseva 1977, Gritsenko \& Gursenkov 1983; Friesen 1983, 1985, 1986, 1988, Krogulevich \& Rostovtseva 1984, Rudyka 1984, Krasnikov 1985, Probatova et al. 2011). Noteworthy, in plants from SE Transbaikalia (neighboring to China) we revealed both $(2 x$ and $4 x)$ races.

\section{A MARA N TH A CEAE}

Amaranthus blitoides S. Watson, 2n = 32 .

IRKU C799, Russia, Zabaikalskii Krai, Borzinskii Raion, Soloviovsk village, near a fence, $608 \mathrm{~m}$ alt., $49^{\circ} 53^{\prime} \mathrm{N}, 115^{\circ} 45^{\prime} \mathrm{E}$, 29.VII.2008, coll. V. Chepinoga, S. Rosbakh \& A. Konovalov. First count in Siberia.

This cosmopolitan species is probably tetraploid $(x=8)$ and its chromosome number has been reported many times (see Index... 1981, 1988, 1990, 1991, 1994, 1996, 2006, Probatova et al. 2009).

\section{A S PA RA GACEAE}

*Asparagus brachyphyllus Turcz., $2 \mathrm{n}=20$.

IRKU C854, Russia, Zabaikalskii Krai, Borzinskii Raion, 10 km N of Soloviovsk village, between Zun-Torei and Barun-Torei lakes, steppe, $593 \mathrm{~m}$ alt., $49^{\circ} 58^{\prime} \mathrm{N}, 115^{\circ} 43^{\prime} \mathrm{E}, 27 . \mathrm{VII} .2008$, coll. M. Isaikina, K. Fleckenstein \& N. Pazdnikova.

A. brachyphyllus is mainly Daurian species, it occurs in Russia in SE Transbaikalia only. The only known chromosome count $(4 x$ $2 \mathrm{n}=40$ ) was made for $A$. brachyphyllus from plants cultivated in the Omsk botanical garden (Zakharjeva \& Makushenko 1969). The origin of these plants is unknown, but most likely they were collected in surroundings of Omsk city (SW Siberia). If this hypothesis is true, then the published count belongs not to $A$. brachyphylllus but to $A$. pallasii Miscz., which had not been distinguished from $A$. braphyphyllus at the time when the cited work was done. In this case our count of chromosome number is the first count for $A$. brachyphyllus s. str. The same chromosome number $2 \mathrm{n}=20$ was independently obtained in $A$. brachyphyllus from plants collected by $\mathrm{S}$. Kazanovsky at the northern shore of Zun-Torei Lake (N. Probatova, pers. comm.).

Closely related species (A. brachyphyllus, A. pallasii, A. tamariscinus Ivanova ex Grubov, $A$. trichophyllus Bunge) are distinguished mostly on the geographical basis, while morphological differences are weak and unstable (Vlassova 1989, Gubanov 1996, Chen \& Tamanian 2000). We tend to support the opinion by V. Grubov (1977), who considered all these species as $A$. trichophyllus s. 1. Further studies applying methods of karyology and molecular markers (see, for example: Fukuda et al. 2005) are needed to elucidate relationships within this taxon.

Asparagus davuricus Fisch. ex Link

(incl. A. burjaticus Peschkova), $\mathbf{2 n}=\mathbf{2 0}$.

IRKU C856, Russia, Zabaikalskii Krai: Mogoituyskii Raion, $6 \mathrm{~km} \mathrm{NE} \mathrm{Kusocha} \mathrm{village,} \mathrm{floodplain} \mathrm{of} \mathrm{right} \mathrm{riverside} \mathrm{of}$ the Onon River, floodplain, shore of the quarry lake, $571 \mathrm{~m}$ alt., $50^{\circ} 44^{\prime} \mathrm{N}, 115^{\circ} 42^{\prime} \mathrm{E}, 14 . \mathrm{VII} .2008$, coll. V. Chepinoga \& S. Rosbakh; IRKU C857, C875, Borzinskii Raion, $10 \mathrm{~km} \mathrm{~N}$ of Soloviovsk village, between Zun-Torei and Barun-Torei lakes, steppe, $593 \mathrm{~m}$ alt., $49^{\circ} 58^{\prime} \mathrm{N}, 115^{\circ} 43^{\prime} \mathrm{E}, 27 . V I I .2008$, coll. M. Isaikina, K. Fleckenstein \& N. Pazdnikova; IRKU C860, C876, Borzinskii Raion, $15 \mathrm{~km} \mathrm{~S}$ of Kulussutai village, between Zun-Torei and Barun-Torei lakes, feather grass steppe, $601 \mathrm{~m}$ alt., $50^{\circ} 06^{\prime} \mathrm{N}, 115^{\circ} 41^{\prime} \mathrm{E}, 28 . \mathrm{VII} .2008$, coll. V. Chepinoga, S. Rosbakh \& P. Lubogoschinsky.

$*-2 \mathrm{n}=40$.

IRKU C761, Russia, Zabaikalskii Krai, Borzinskii Raion, 15 $\mathrm{km} \mathrm{S}$ of Kulussutai village, between Zun-Torei and Barun-Torei lakes, feather grass steppe, $601 \mathrm{~m}$ alt., $50^{\circ} 06^{\prime} \mathrm{N}, 115^{\circ} 41^{\prime} \mathrm{E}$, 28.VII.2008, coll. P. Lubogoschinsky.

The reports of chromosome numbers for $A$. davuricus were made from Zabaikalskii Krai $(2 \mathrm{n}=20$, Borzia town and Kazanovo village - Vlassova 1981, Krogulevich \& Rostovtseva 1984) and China $(2 \mathrm{n}=18$; see Index ... 2003). The $2 \mathrm{n}=20$ was also obtained independently in $A$. davuricus from plants collected by S. Kazanovsky in the Adon-Chelon mountain-steppe massif (SE Transbaikalia), but for $A$. burjaticus it was $2 \mathrm{n}=40$, from plants collected by D. Krivenko along the Selenga River (Southern Buryatia) (N. Probatova, pers. comm.).

A. davuricus and $A$. burjaticus are closely related species with unstable morphological differences; nevertheless the difference in ploidy levels can be a good reason to consider these two taxa as separate species.

\section{Asparagus gibbus Bunge, 2n $=\mathbf{4 0}$.}

IRKU C858, Russia, Zabaikalskii Krai: Borzinskii Raion, 12 $\mathrm{km} \mathrm{E}$ of Soloviovsk village, on the shore of Zun-Torei lake, $597 \mathrm{~m}$ alt., 49 $59^{\prime} \mathrm{N}, 115^{\circ} 50^{\prime} \mathrm{E}$, 29.VII.2008, coll. V. Chepinoga, S. Rosbakh \& A. Konovalov; IRKU C859, C871, C873, Borzinskii Raion, $15 \mathrm{~km} \mathrm{~S}$ of Kulussutai village, between ZunTorei and Barun-Torei lakes, feather grass steppe, $601 \mathrm{~m}$ alt., $50^{\circ} 06^{\prime} \mathrm{N}, 115^{\circ} 41^{\prime} \mathrm{E}, 28 . \mathrm{VII} .2008$, coll. V. Chepinoga, S. Rosbakh \& P. Lubogoschinsky.

The unique report of chromosome number for $A$. gibbus $(2 \mathrm{n}=$ 40) was made from the same region, the lake Zun-Torei (Vlassova 1981, Krogulevich \& Rostovtseva 1984). In A. gibbus, identified according to morphological characters reported by Vlassova (2001), we found tetraploid chromosome number $2 \mathrm{n}$ $=40$ as well. $A$. gibbus is closely related to $A$. davuricus and the morphological differences between these species are weak and unstable.

\section{B ORA GINACEAE}

Tournefortia sibirica L. (Argusia rosmarinifolia (Willd.) Steven, $A$. sibirica (L.) Dandy), $2 \mathbf{n}=26$. 
IRKU C690, Russia, Zabaikalskii Krai, Ononskii Raion, 8 km $\mathrm{NE}$ of Builessan village, saline lake Khotochei, lakeshore, 678 $\mathrm{m}$ alt., $50^{\circ} 18^{\prime} \mathrm{N}, 114^{\circ} 57^{\prime} \mathrm{E}, 02$.VI.2008, coll. P. Lubogoschinsky. First count in Siberia.

We found two references to the counts of chromosome number of this E European-Asian species. The first we found in "Flora of China" ( $2 \mathrm{n}=26$; Zi 1995); however, we were unable to discover the primary source of these data. The second was published on the material from Russian Far East (Probatova et al. 2010, as Argusia sibirica). The chromosome number of the species was $2 \mathrm{n}=26$ in both cases. Plants from Transbaikalia confirm the diploid chromosome number of $T$. sibirica.

\section{$F A B A C E A E$}

\section{*Lupinaster popovii Roskov, 2n = 32 .}

IRKU C720, Russia, Zabaikalskii Krai, Mogoituyskii Raion, 2 $\mathrm{km} \mathrm{SW}$ of Yasnogorsk town, near the mouth of the Turga River, sandy roadside, $582 \mathrm{~m}$ alt., $50^{\circ} 50^{\prime} \mathrm{N}, 115^{\circ} 40^{\prime} \mathrm{E}, 12$.VII.2008, coll. P. Lubogoschinsky.

This species, described from Baikal Siberia, is a poorly delineated race of L. pentaphyllus Moench s. 1. L. pentaphyllus has two ploidy levels: more common is tetraploid $(2 \mathrm{n}=4 x=32$; Belaeva \& Siplivinsky 1975, Krogulevich 1978, Probatova et al. 2008a, Krivenko et al. 2011) and less common is hexaploid (2n $=6 x=48$; Belaeva \& Siplivinsky 1975, Krogulevich \& Rostovtseva 1984). Hexaploid race of L. pentaphyllus was described as a separate species, L. baicalensis (Belyaeva et Sipliv.) Roskov (=Trifolium baicalense Belyaeva et Sipliv.), which has pinkishwhite flowers, while the flowers of $L$. pentaphyllus s. str. are red-violet. $L$. popovii has the same chromosome number as $L$. pentaphyllus s. str. and differs from it mainly by quantitative features: plants are stocky, with numerous stems, smaller leaves and smaller flowers. A more detailed karyological study of L. pentaphyllus s. l. complex is needed.

\section{H A L O RA G A CEA E}

\section{Myriophyllum sibiricum Kom., 2n = 28.}

IRKU C372, Russia, Zabaikalskii Krai: Uletovskii Raion, 28 $\mathrm{km} \mathrm{W}$ of Tanga village, Areiskoe lake, submerged, $50^{\circ} 58^{\prime} \mathrm{N}$, 1113'ㄹ'E, 15.VI.2007, coll. A. Gnutikov \& I. Enushchenko; IRKU C669, Ononskii Raion, 6 km W of Nizhnii Zassuchey village, right riverside of the Onon River, floodplain, oxbow lake, in shallow water, $663 \mathrm{~m}$ alt., $50^{\circ} 31^{\prime} \mathrm{N}, 115^{\circ} 02^{\prime} \mathrm{E}$, 27.VI.2008, coll. P. Lubogoschinsky \& V. Chepinoga; IRKU C735, Aginskii Raion, $8 \mathrm{~km} \mathrm{~W}$ of Gunei village, left riverside of the Onon River, oxbow lake Krivoye, in shallow water, 655 $\mathrm{m}$ alt., $50^{\circ} 30^{\prime} \mathrm{N}, 114^{\circ} 25^{\prime} \mathrm{E}, 18$.VII.2008, coll. P. Lubogoschinsky, S. Rosbakh \& V. Chepinoga; IRKU C777, Ononskii Raion, $6 \mathrm{~km} \mathrm{~W}$ of Nizhnii Zassuchey, floodplain of right riverside of the Onon River, oxbow lake Pashutkino, submerged, $663 \mathrm{~m}$ alt., $50^{\circ} 31^{\prime} \mathrm{N}, 115^{\circ} 02^{\prime} \mathrm{E}, 05 . \mathrm{VIII} .2008$, coll. P. Lubogoschinsky. Counts from Transbaikalia confirm the tetraploid chromosome number $(2 \mathrm{n}=4 x=28)$ in $M$. sibiricum that we obtained earlier on the material from Cisbaikalia (Irkutskaya Oblast'; Probatova et al. 2008a). It should be stressed that for North American M. exalbescens Fernald, which is commonly considered as a synonym of $M$. sibiricum, only hexaploid number $(2 \mathrm{n}=$ 48) was reported from U.S.A. (Aiken 1978) and Canada (Löve \& Löve 1982).

\section{*Myriophyllum verticillatum L., 2n = 14 .}

IRKU C270, Russia, Republic of Buryatia, Mukhorshibirskii Raion, left riverside of the Khilok River, opposite of Podlopatki village, small oxbow, submerged, $50^{\circ} 54^{\prime} \mathrm{N}, 1^{\circ} 07^{\circ} 04^{\prime} \mathrm{E}$, 13.VI.2006, coll. I. Enushchenko \& I. Salovarov; IRKU C619, Zabaikalskii Krai, Uletovskii Raion, $2 \mathrm{~km}$ N of Cheremkhovo village, steppe lake Nympheinikovoye, in shallow water, 725 $\mathrm{m}$ alt., $51^{\circ} 28^{\prime} \mathrm{N}, 112^{\circ} 43^{\prime} \mathrm{E}, 12 . \mathrm{VII} .2007$, coll. A. Gnutikov \& I. Enushchenko. First count in Siberia.
Several chromosome counts from the Russian Far East revealed $2 \mathrm{n}=4 x=28$ (see Index ... 1998, 2000, 2006, etc.). Nevertheless from Transbaikalia we obtained (twice) the diploid chromosome number $(2 \mathrm{n}=14)$. None of the four known diploid species of the genus Myriophyllum (M. alternifolium DC., M. propinquum A. Cunn., M. tenellum Bigelow, $M$. ussuriense Maxim.: see Index ... 1984, 1985, 1990, 1996, 2003, 2010) was found so far in Siberia. Distribution range of M. ussuriense is relatively close to Siberia, but this species (dioecious, subtile, often with reduced number of lobes of the leaves) differs substantially from plants investigated by us. A more detailed karyological study on $M$. verticillatum, as well as the genus Myriophyllum in Siberia is needed to clarify the problem outlined above.

\section{PA PAVERACEAE}

Chelidonium asiaticum (Hara) Krahulc., 2n $=\mathbf{1 0}$.

IRKU C683, Russia, Zabaikalskii Krai, Ononskii Raion, Nizhnii Zassuchey village, on roadside, $647 \mathrm{~m}$ alt., $50^{\circ} 30^{\prime} \mathrm{N}$, $115^{\circ} 06^{\prime} \mathrm{E}, 01 . \mathrm{VII} .2008$, coll. P. Lubogoschinsky.

Ch. asiaticum is an East Asian vicariant of Ch. majus L. s. l., differing by the lower number of chromosomes $-2 \mathrm{n}=10$ (cf. $2 \mathrm{n}=12$ of (h. majus). Ch. asiaticum has some morphological differences from Ch. majus: it is slightly more hairy, with a bit narrower and subacute lobes of the leaves (Krahulcová 1982). Earlier it was thought that $C h$. asiaticum is limited to East Asia, and that in Russia it occurs in the Far East. Really, only Ch. asiaticum is presented in the Russian Far East. However, the karyological study demonstrated that both $C h$. asiaticum and Ch. majus occur in the Baikal Siberia (Belaeva \& Siplivinsky 1975, Safronova 1991, Chepinoga et al. 2008, Probatova et al. 2008b, 2008c, 2008d), Ch. asiaticum exists also at the west coast of the Baikal Lake (Fig. 1). Noteworthy, a Chelidonium with $2 \mathrm{n}=10$ was once reported from West Siberia (the vicinity of Tomsk city; Kartashova et al. 1974). We doubt that the distribution range of Ch. asiaticum really reaches West Siberia. Still the problem requires further investigation.

Chelidonium majus L., 2n $=12$.

IRKU C131, 132, Russia, Irkutskaya Oblast', Shelekhovskii Raion, surroundings of Bolshoi Lug village, anthropogenic meadow, $52^{\circ} 06^{\prime} \mathrm{N}, 104^{\circ} 06^{\prime} \mathrm{E}, 02 . \mathrm{V} .2005$, coll. V. Chepinoga.

According to A. Krahulcová (1982), Ch. majus is Eurasian species (also known from North America as an introduced plant), but this species is absent in the Russian Far East (Bezdeleva 1987). As stated above, both this species and Ch. asiaticum occur in the Baikal Siberia (Fig. 1).

\section{POACEAE}

\section{Hordeum brevisubulatum Link, 2n = 28 .}

IRKU C364, Russia, Republic of Buryatia, Mukhorshibirskii Raion, $15 \mathrm{~km}$ NNW of Mukhorshibir village, a pond on the tributary of the Tugnui River, on the bank, $51^{\circ} 11^{\prime} \mathrm{N}, 107^{\circ} 16^{\prime} \mathrm{E}$, 14.VI.2007, coll. A. Gnutikov \& I. Enushchenko; IRKU C728, Russia, Zabaikalskii Krai: Aginskii Raion, $8 \mathrm{~km} \mathrm{~W}$ of Gunei village, left riverside of the Onon River, oxbow lake Krivoye, in shrubs on the shore, $655 \mathrm{~m}$ alt., $50^{\circ} 30^{\prime} \mathrm{N}, 114^{\circ} 25^{\prime} \mathrm{E}$, 17.VII.2008, coll. P. Lubogoschinsky; IRKU C812, Ononskii Raion, $8 \mathrm{~km}$ SSE of Bolshevik village, the saline lake Balyktui, steppe-meadow on the shore, $676 \mathrm{~m}$ alt., $50^{\circ} 24^{\prime} \mathrm{N}, 114^{\circ} 42^{\prime} \mathrm{E}, 04$.VI.2008, coll. M. Isaikina \& P. Lubogoschinsky.

H. brevisubulatum is an Asian forest-steppe species with constant chromosome number. Earlier data from the Baikal Siberia exist for plants from East Sayan Mts. (Krogulevich 1978) and SE Transbaikalia (Probatova et al. 2011).

\section{Hordeum roshevitzii Bowden, 2n = 14.}

IRKU C809, Russia, Zabaikalskii Krai: Ononskii Raion, 15 km W of Ust'-Imalka village, saline lake Bulun-Zagan, moist meadow on the shore, $653 \mathrm{~m}$ alt., $50^{\circ} 07^{\prime} \mathrm{N}, 115^{\circ} 06^{\prime} \mathrm{E}, 25 . \mathrm{VII} .2008$, coll. V. Chepinoga; IRKU C866, Ononskii Raion, $10 \mathrm{~km} \mathrm{SE}$ 


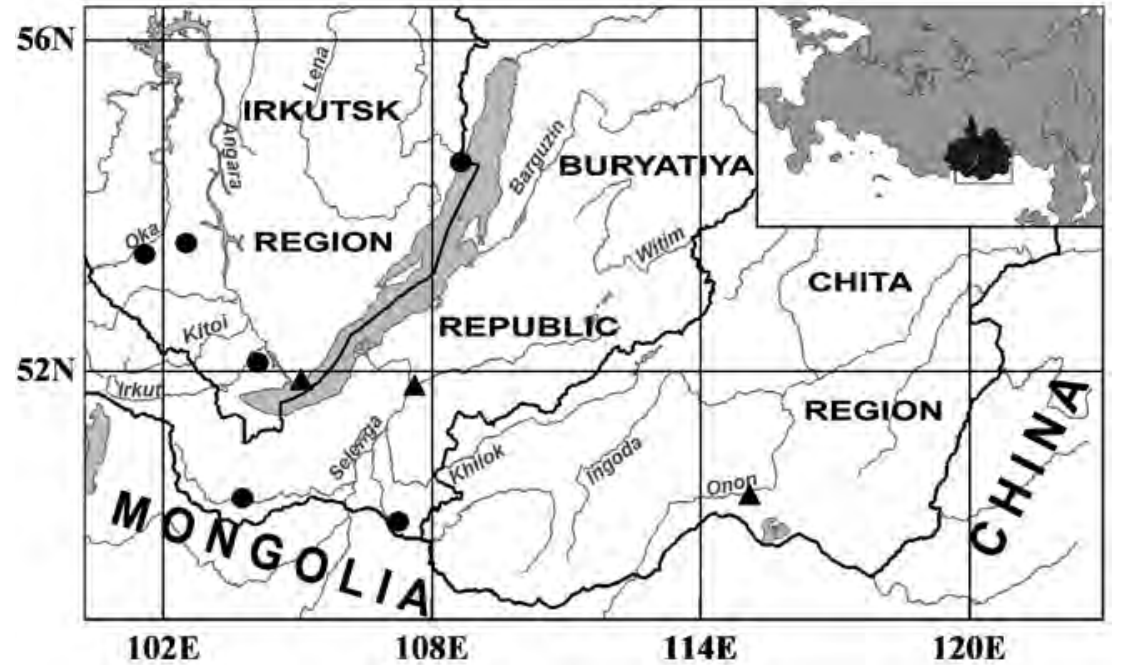

Figure 1 Localities of specimens of Chelidonium with chromosome numbers studied, in the Baikal Siberia. Triangles - Ch. asiaticum, dots - Ch. majus (sources: Belaeva \& Siplivinsky 1975, Safronova 1991, Chepinoga et al. 2008, Probatova et al. 2008b, 2008c, 2008d; this study). of Builessan village, saline lake Zagan-Nor, on shore, $678 \mathrm{~m}$ alt., $50^{\circ} 11^{\prime} \mathrm{N}, 114^{\circ} 57^{\prime} \mathrm{E}, 24$.VII.2008, coll. P. Lubogoschinsky. Previous studies demonstrated that $H$. roshevitzii is a diploid species: $2 \mathrm{n}=2 \mathrm{x}=14$, the only report of $2 \mathrm{n}=28$ is doubtful (see Index ... 1984).

\section{Lolium multiflorum Lam., 2n = 14.}

IRKU C835, Russia, Irkutskaya Oblast', Shelekhovskii Raion, downtown of Shelekhov town, in the pine forest edge, $52^{\circ} 12^{\prime} \mathrm{N}, 104^{\circ} 04^{\prime} \mathrm{E}, 25 . \mathrm{VII} .2004$, coll. N. Dulepova. First count in Siberia.

L. multiflorum is alien species in the Baikal Siberia, where it is cultivated on lawns. Diploid chromosome number $(2 n=14)$ is the most common (see Index ... 1998, 2006).

\section{PRIMULACEAE}

*Primula serrata Georgi, $2 \mathbf{n}=18$.

IRKU C657, Russia, Zabaikalskii Krai, Uletovskii Raion, 3 $\mathrm{km} \mathrm{NE}$ of Cheremkhovo village, left riverside of the Ingoda River, wet meadow, $51^{\circ} 28^{\prime} \mathrm{N}, 112^{\circ} 44^{\prime} \mathrm{E}, 24$.VI.2008, coll. P. Lubogoschinsky.

P. serrata is an Asian species growing on wet meadows.

\section{ROS ACEAE}

Waldsteinia ternata Fritsch, 2n $=28$.

IRKU C1067, Russia, Republic of Buryatia, Kabanskii Raion, Khamar-Daban Mountain Range, 1,5 km S of Baikal Lake, lower course of the Anossovka River, Populus forest, $470 \mathrm{~m}$

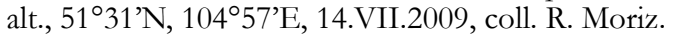

\section{$-2 n=42$.}

IRKU C958, Russia, Irkutskaya Oblast', Sludyanskii Raion, Khamar-Daban Mountain Range, $10 \mathrm{~km} \mathrm{~S}$ of Baikal Lake, lower course of the Snezhnaya River, Teplye Lakes, on the shore nearby the forest edge, $492 \mathrm{~m}$ alt., $51^{\circ} 23^{\prime} \mathrm{N}, 104^{\circ} 38^{\prime} \mathrm{E}$, 01.VII.2009, coll. V. Chepinoga \& R. Moriz.

Nemoral relict species described from the Khamar-Daban Range (south coast of the Baikal Lake). Geographically separated populations from Europe and from the Russian Far East were recognized as two subspecies $W$. ternata ssp. trifolia (Rochel ex W. D. J. Koch) Teppner and W. ternata ssp. maximowicziana Teppner, respectively. Some researches treat these taxa as species ( $W$. trifolia Rochel ex W.D.J. Koch, W. maximowicziana (Teppner) Prob.). In all parts of the geographical range of $W$. ternata s. 1., except for one (in Romania), more than one ploidy level occur: Carinthia (Austria) / Slovenia $-4 x, 5 x$,
Slovakia $-4 x, 5 x$, Romania $-6 x$, Southern Siberia $-2 x, 6 x$ and Eastern Asia - 2x, 4x, 6x (Stepanov 1994, Teppner 2003, Probatova et al. 2006, Teppner et al. 2009). Earlier information from South Siberia originated from Krasnoyarskii Krai $(2 \mathrm{n}=2 x=14$; Stepanov 1994, as $W$. tansybeica Stepanov) and from Khamar-Daban Range ( $\mathrm{n}=6 x=42$; Teppner 2003). Our data confirm the occurrence of hexaploids $(2 n=42)$ in the Khamar-Daban Range, where we also found a new, tetraploid cytotype $(2 \mathrm{n}=28)$. These findings support the opinion by $\mathrm{H}$. Teppner that "such a pattern makes the independent, convergent evolution of the different ploidy levels probable" (Teppner et al. 2009: 231).

\section{$R U B I A C E A E$}

*Galium paradoxum Maxim., 2n $=22$.

IRKU C951, Russia, Irkutskaya Oblast', Sludyanskii Raion, Khamar-Daban Range, $8 \mathrm{~km} \mathrm{~S}$ of Baikal Lake, lower course of the Snezhnaya River, Populus forest edge, $506 \mathrm{~m}$ alt., $51^{\circ} 24^{\prime} \mathrm{N}$, $104^{\circ} 38^{\prime} \mathrm{E}, 30$. VI.2009, coll. R. Moriz.

G. paradoxum is an East Asian plant growing in shady coniferous and mixed forests.

\section{Galium ruthenicum Willd., 2n $=44$.}

IRKU C703, Russia, Zabaikalskii Krai, Ononskii Raion, Nizhnii Zassuchey village, on the roadside, $647 \mathrm{~m}$ alt., $50^{\circ} 30^{\prime} \mathrm{N}$, $115^{\circ} 06^{\prime} \mathrm{E}, 07 . \mathrm{VII} .2008$, coll. P. Lubogoschinsky.

Our data confirm the tetraploid $(x=11)$ chromosome number for the species reported earlier from the Russian Far East (Probatova \& Sokolovskaya 1989). Importantly, the closely related G. verum L. also has $2 \mathrm{n}=44$. First count in Siberia.

\section{ACKNOWLEDGEMENTS}

We are grateful to Dr. Nina S. Probatova (Vladivostok) for the revision of an earlier version of the manuscript, valuable discussions and information on unpublished results.

The study was financially supported by the Russian Foundation for Basic Research (05-05-64061-a, 11-0400240-a,), by Ministry of Education and Science of Russian Federation (RNP.2.2.3.1.4667) and by the Erasmus Mundus External Cooperation Window Programme (TRIPLEI2010364). 


\section{LITERATURE CITED}

Agapova, N. D., K. B. Arkharova, L. I. Vakhtina, E. A. Zemskova \& L. V. Tarvis 1990. Chromosome numbers in flowering plants of the flora of the USSR: Aceraceae - Menyanthaceae. Nauka, Leningrad, 509 pp. (in Russian). [Агапова Н.А., Архарова К.Б., Вахтина А.И., Земскова Е.А., Тарвис А.В. 1990. Числа хромосом цветковых растений фморы СССР: Семейства Aceraceae Menyanthaceae. $\Lambda .:$ Наука. 509 c.]

Aiken, S. 1978. In: IOPB chromosome reports LXII (Á. Löve, ed.) Taxon 27(5-6):522.

Belaeva, V. A. \& V. N. Siplivinsky 1975. Chromosome numbers and taxonomy of some species from the flora of the Baikal Region 1. Botanicheskii Zhurnal 60(6):864-872 (in Russian). [Beмяева В.А., Сипливинский В.Н. 1975. Хромосомные числа и таксономия некоторых видов Байкальской фморы, $1 / /$ Ботанический журнал. Т. 60, № 6. С. 864-872.]

Belaeva, V.A. \& V.N. Siplivinsky 1981. In: Chromosome number reports LXXIII (Á. Löve, ed.) Taxon 30(4):857-860.

Bezdeleva, T. A. 1987. Fam. Papaveraceae. In: Vascular plants of the Soviet Far East (S. S. Kharkevich, ed.), vol. 2, pp. 37-69, Nauka, Leningrad (in Russian). [Безделева T.A. 1987. Сем. Маковые - Papaveraceae // Сосудистые растения советского Аальнего Востока. А.: Наука. T. 2. С. 37-69.]

Chen, S.-C. \& K. G. Tamanian 2000. Asparagus L. In: Flora of China (Zh. Wu \& P. H. Raven, eds.), vol. 24. Flagellariaceae through Marantaceae, pp. 208-215. Science Press, Beijing \& Missouri Botanical Garden Press, St. Louis.

Chepinoga, V. V., A. A. Gnutikov \& I. V. Enuschenko 2008. Chromosome numbers in some species of vascular plants of the Baikal Siberia. Botanicheskii Zhurnal 93(8):1286-1295 (in Russian). [Чепинога В.В., Гнутиков А.А., Енущенко И.В. 2008. Числа хромосом некоторых видов сосудистых растений фморы Байкальской Сибири // Бот. журн. Т. 93, № 8. С. 1286-1295.]

Chepinoga, V. V., A. A. Gnutikov, I. V. Enushchenko \& S. A. Rosbakh 2009. In: IAPT/IOPB chromosome data 8 (K. Marhold, ed.). Taxon 58(4):1281-1282; E1-E3.

Chepinoga, V. V., A. A. Gnutikov \& I. V. Enushchenko 2010a. Chromosome numbers of some plants species from the southern part of East Siberia. Botanicheskii Zhurnal 95(1):129-139 (in Russian). [Чепинога В.В., Гнутиков А.А., Енущенко И.В. 2010. Числа хромосом некоторых виАов растений из южной части Восточной Сибири // Бот. журн. Т. 95, № 1. С. 129-139.]

Chepinoga, V. V., A. A. Gnutikov \& I. V. Enushchenko 2010b. In: IAPT/IOPB chromosome data 9 (K. Marhold, ed.). Taxon 59(4):1298-1299; E1-E5.

Friesen, N. V. 1983. Cytotaxonomical study of some species of Allium L. in Siberia. Iqvestiya Sibirskogo otdeleniya AN SSSR. Ser. Biol. Nauk 5(1):48-52 (in Russian). [Фризен H.В. 1983. Цитотаксономическое исследование некоторых видов рода Alli$u m$ L. в Сибири // Изв. СО АН СССР. Сер. биол. наук. Т. 5, № 1. C. 48-52.]

Friesen, N. V. 1985. Chromosome numbers in some species of the family Alliaceae from Siberia. Botanicheskii Zhurnal 70(7):10011002 (in Russian). [Фризен Н.В. 1985. Числа хромосом преАставителей семейства Alliaceae из Сибири // Бот. журн. Т. 70, № 7. C. 1001-1002.]

Friesen, N. V. 1986. Chromosome numbers in some species of the family Alliaceae from Siberia. Botanicheskii Zhurnal 71(1): 113-115 (in Russian). [Фризен Н.В. 1986. Числа хромосом представителей семейства Alliaceae из Сибири / / Бот. журн. T. 71, № 1. C. 113-115.]

Friesen, N. V. 1988. Onion family in Siberia. Systematics, karyology, chorology. Nauka, Novosibirsk, 185 pp. (in Russian). [Фризен H.B. 1988. Ауковые Сибири. Систематика, кариология, хорология. Новосибирск: Наука. 185 с.]

Friesen, N. V. 1991. Chromosome numbers in some species of the Alliaceae from Siberia. Botanicheskii Zhurnal 76(1):141-142 (in Russian). [Фризен Н.В. 1991. Числа хромосом представителей семейства Alliaceae из Сибири // Бот. журн. Т. 76, № 1. С. 141-142.]
Fukuda, T., H. Ashizawa, R. Suzuki, T. Ochiai, T. Nakamura, A. Kanno, T. Kameya \& J. Yokoyama 2005. Molecular phylogeny of the genus Asparagus (Asparagaceae) inferred from plastid petB intron and petD-rpoA intergenic spacer sequences. Plant Species Biology 20:121-132.

Index to plant chromosome numbers 1975-1978 (P. Goldblatt, ed.) 1981. Monographs in Systematic Botany, Missouri Botanical Garden, USA 5:1-553.

Index to plant chromosome numbers 1979-1981 (P. Goldblatt, ed.) 1984. Ibid. 8:1-427.

Index to plant chromosome numbers 1982-1983 (P. Goldblatt, ed.) 1985. Ibid. 13:1-224.

Index to plant chromosome numbers 1984-1985 (P. Goldblatt, ed.) 1988. Ibid. 23:1-264.

Index to plant chromosome numbers 1986-1987 (P. Goldblatt \& D. E. Johnson, eds.) 1990. Ibid. 30:1-243.

Index to plant chromosome numbers 1988-1989 (P. Goldblatt \& D. E. Johnson, eds.) 1991. Ibid. 40:1-238.

Index to plant chromosome numbers 1990-1991 (P. Goldblatt \& D. E. Johnson, eds.) 1994. Ibid. 51:1-267.

Index to plant chromosome numbers 1992-1993 (P. Goldblatt \& D. E. Johnson, eds.) 1996. Ibid. 58:1-276.

Index to plant chromosome numbers 1994-1995 (P. Goldblatt \& D. E. Johnson, eds.) 1998. Ibid. 69:1-208.

Index to plant chromosome numbers 1996-1997 (P. Goldblatt \& D. E. Johnson, eds.) 2000. Ibid. 81:1-188.

Index to plant chromosome numbers 1998-2000 (P. Goldblatt \& D. E. Johnson, eds.) 2003. Ibid. 94:1-297.

Index to plant chromosome numbers 2001-2003 (P. Goldblatt \& D. E. Johnson, eds.) 2006. Ibid. 106:1-242.

Index to plant chromosome numbers 2004-2006 (P. Goldblatt \& D. E. Johnson, eds.) 2010. Regnum Vegetable 152:1-256.

Gritsenko, P. P. \& N. N. Gurzenkov 1983. Karyosystematic investigation of onions species from the Russian Far East. Abstracts of 7 th Congress of the Russian Botanical Society. Donezk, p. 16 (in Russian). [Гриценко П.П., Гурзенков Н.Н. 1983. Кариосистематическое изучение дальневосточных видов мука // Тез. докл. 7-го делег. съезАа Всесоюз. бот. общ-ва. Аонецк. С. 16.]

Grubov, V. I. 1977. Asparagus L. In: Plants of the Central Asia. Vol. 7. Liliaceae - Orchidaceae (V. I. Grubov, ed.), pp. 77-82, Nauka, Leningrad (in Russian). [Грубов В.И. 1977. Растения Центральной Азии. АенинграА: Наука. С. 77-82.]

Gubanov, I. A. 1996. Check-list of the flora of the Outer Mongolia (vascular plants). Walang, Moscow, 136 pp. (in Russian). [ [Yyбанов И.А. 1996. Конспект фморы Внешней Монголии (сосудистые растения). Москва: Валанг. 136 с.]

Hongguan, T., L. Meng, S. Ao \& J. Liu 2005. Origin of the Qinghai-Tibetan Plateau endemic Milula (Lilaceae): further insights from karyological comparisons with Allium. Caryologia 58(4):320-331.

Kartashova, N. N., L. A. Malakhova \& A. A. Kozlova 1974. Studies on chromosomes in some plants of Ob' region. 1. Chromosome number of some plant species from Tomsk Oblast'. Nauchnie Doklady Vysshei Sbkoly. Biol. Sci. 4:114-119 (in Russian). [Карташова Н.Н., Малахова А.А., Козмова А.А. 1974. Изучение хромосом представителей Приобья. 1. Число хромосом некоторых видов растений Томской области // Научные Аоклады высшей школы. Биологические науки. Т. 4. C. $114-119$.]

Krahulcová, A. 1982. Cytotaxonomic study of Chelidonium majus L. s.l. Folia Geobotanica et Phytotaxonomica 17:237-268.

Krasnikov, A. A. 1985. Chromosome numbers in some species of Alliaceae from Altai and Tuva ASSR. Botanicheskii Zhurnal 70(6):858-859 (in Russian). [Красников А.А. 1985. Числа хромосом преАставителей семейства Alliaceae с А^тая и Тувинской АССР // Бот. журн. Т. 70, № 6. С. 858-859.]

Krivenko, D. A., V. V. Kotseruba, S. G. Kazanovsky, A. V. Verkhozina \& N. V. Stepanov 2011. In: IAPT/IOPB chromosome data 11 (K. Marhold, ed.). Taxon 60(4):1222; E12-E13.

Krogulevich, R. E. 1976. Chromosome numbers in some plant species from Tunkinskii Ridge (East Sayan Mts.). Izvestiya Sibirskogo otdeleniya AN SSSR. Ser. Biol. Nauk 15(3):46-52 (in Russian). 
[Крогулевич Р.Е. 1976. Числа хромосом некоторых видов растений Тункинских альп (Вост. Саян) // Изв. СО АН СССР. Сер. биол. наук. Т. 15, № 3. С. 46-52.]

Krogulevich, R. E. 1978. Karyological analysis of the flora of the East Sayan Mts. In: Flora of the Cisbaikalia, pp. 19-48. Nauka, Novosibirsk (in Russian). [Крогулевич P.E. 1978. Кариологический анализ видов флоры Восточного Саяна // Фмора Прибайкамья. Новосибирск: Наука. С. 19-48.]

Krogulevich, R. E. \& T. S. Rostovtseva 1984. Chromosome numbers of the flowering plants in Siberia and Far East. Nauka, Novosibirsk, 286 pp. (in Russian). [Крогулевич P.Е., Ростовцева T.C. 1984. Хромосомные числа цветковых растений Сибири и Аальнего Востока. Новосибирск: Наука. 286 с.]

Löve, Á. \& D. Löve 1982. In: IOPB chromosome reports LXXV (Á. Löve, ed.). Taxon 31(2):344-360.

Probatova, N. S. \& A. P. Sokolovskaya 1989. Chromosome numbers in vascular plants from Primorskii Krai, the Amur region, Sakhalin, Kamchatka and the Kuril Islands. Botanicheskii Zhurnal 74(1):120-123 (in Russian). [Пробатова Н.С., Соколовская А.П. 1989. Числа хромосом сосудистых растений из Приморья, Приамурья, Сахалина, Камчатки и Курильских островов // Бот. журн. Т. 74, № 1. С. 120-123.]

Probatova, N. S., E. G. Rudyka, A. V. Shatokhina, V. Yu. Barkalov, M. V. Krjukova \& D. Yu. Tzyrenova 2006. Chromosome numbers of some plant species of the Primosky Territory and the Amur River basin. Botanicheskii Zhurnal 91(5):785-804 (in Russian). [Пробатова Н.С., Рудыка Э.Г., Шатохина А.В., Баркалов В.Ю., Крюкова М.В., Цыренова А.Ю. 2006. Числа хромосом видов флоры Приморского края и Приамурья // Бот. журн. Т. 91, № 5. С. 785-804.]

Probatova, N. S., A. A. Gnutikov, E. G. Rudyka \& V. V. Chepinoga 2008a. Chromosome numbers of some plant species from Baikal Siberia. Botanicheskii Zburnal 93(1):162-181 (in Russian). [Пробатова Н.С., Гнутиков А.А., Рудыка Э.Г., Чепинога В.В.] [Числа хромосом виАов растений из Байкальской Сибири // Бот. журн. Т. 93, № 1. С. 162-181.]

Probatova, N. S., E. G. Rudyka, V. P. Seledets \& V. A. Nechaev 2008b. In: IAPT/IOPB chromosome data 6 (K. Marhold, ed.). Taxon 57(4):1268-1271; E4-E12.

Probatova, N. S., V. P. Seledets, A. A. Gnutikov \& A. V. Shatokhina 2008c. In: IAPT/IOPB chromosome data 6 (K. Marhold, ed.). Taxon 57(4):1272-1273; E12-E16.

Probatova, N. S., V. P. Seledets \& E. G. Rudyka 2008d. In: IAPT/ IOPB chromosome data 5 (K. Marhold, ed.). Taxon 57(2):558562; E16-E24.

Probatova, N. S., V. P. Seledets, E. G. Rudyka, A. A. Gnutikov, Z. V. Kozhevnikova \& V. Y. Barkalov 2009. In: IAPT/IOPB chromosome data 8 (K. Marhold, ed.). Taxon 58(4):1284-1288; E11-E20.

Probatova, N. S., Z. V. Kozhevnikova, E. G. Rudyka, A. E. Kozhevnikov \& V. A. Nechaev 2010. Chromosome numbers of vascular plant species from the Russian Far East. Botanicheskii Zhurnal 95(7):1008-1020 (in Russian). [Пробатова Н.C., Кожевникова 3.В., Рудыка Э.Г., Кожевников А.Е., Нечаев В.А. 2010. Числа хромосом сосудистых растений с Аальнего Востока России // Бот. журн. Т. 95, № 7. С. 1008-1020.]

Probatova, N. S., S. G. Kazanovsky, E. G. Rudyka, V. Y. Barkalov, V. P. Seledets \& V. A. Nechaev 2011. In: IAPT/IOPB chromosome data 12 (K. Marhold, ed.). Taxon 60(6):1790-1794; E49E59.

Rostovtseva, T. S. 1977. Chromosome numbers of some plant species from the South Siberia. II Botanicheskii Zhurnal 72(7):1034 1042 (in Russian). РРостовцева T.C. 1977. Числа хромосом некоторых видов растений юга Сибири, 2 // Бот. журн. Т. 72, № 7. C. 1034-1042.]

Rudyka, E. G. 1984. Chromosome numbers in vascular plants from southern part of the Soviet Far East. Botanicheskii Zhur- nal 69(12):1699-1700 (in Russian). [Рудыка Э.Г. 1984. Числа хромосом сосудистых растений из южной части советского Аальнего Востока // Бот. журн. Т. 69, № 12. С. 16991700.]

Safronova, I. N. 1991. Chromosome numbers in some species of Papaveraceae. Botanicheskii Zhurnal 76(6):904-905 (in Russian). [Сафронова И.Н. 1991. Числа хромосом некоторых видов семейства Papaveraceae // Бот. журн. Т. 76, № 6. С. 904-905.]

Sokolovskaya, A. P. 1966. Geographic distribution of polyploid plant species. The study on the flora of the Primorskii Krai. Vestnik Leningradskogo Gos. Univ. 1(3):92-106 (in Russian). [Coколовская А.П. 1966. Географическое распространение помиплоидных видов растений. Исследование фморы Приморского края // Вестн. АГУ. Вып. 1, № 3. С. 92-106.]

Stepanov, N. V. 1994. Chromosome numbers in some nemoral species from West Sayan Mts. (Krasnoyarskii Krai) Botanicheskii Zhurnal 79(3):125-128 (in Russian). [Степанов H.B. 1994. Числа хромосом некоторых неморальных видов Западного Саяна (Красноярский кр.) // Бот. журн. Т. 79, № 3. С. 125128.]

Teppner, H. 2003. Erfahrungen mit Ex-situ-Erhaltung im Botanischen Garten des Institutes für Botanik der Universität Graz. Fritschiana (Graz) 39:1-22.

Teppner, H., W. Schuehly \& A. S. Weakley 2009. The chromosome numbers of Waldsteinia (Rosaceae, Colurieae) in North America. Phyton 48(2):225-238.

Tolgor, X.-G., D.-R. Kang Zhang \& T.-S. Zou 1993. Study on Allium of northeast China. Journal of Jilin Agricultural University 15(4):44-48.

Vlassova, N. V. 1981. Genus Asparagus L. in Siberia. In: New information about plant geography in Siberia. , pp. 79-104, Nauka, Novosibirsk (in Russian). [ВАасова H.В. 1981. Род Asparagus L. в Сибири // Новые Аанные о фитогеографии Сибири. Новосибирск: Наука. С. 79-104.]

Vlassova, N. V. 1989. The Asparagus in Siberia. Systematics, anatomy, chorology. Nauka, Novosibirsk, 80 pp. (in Russian). [B $\mathrm{B}_{\wedge-}$ сова Н.В. 1989. Спаржи Сибири. Систематика, анатомия, хорология. Новосибирск: Наука. 80 с.]

Vlassova, N. V. 2001. Asparagus L. In: Flora of Siberia. Vol. 4. Araceae-Orchidaceae (L. I. Malyshev \& G. A. Peshkova, eds.), pp. 99101, Science Publishers, Enfield (USA) \& Plymouth (UK).

Xu, J. \& R. V. Kamelin 2000. Allium L. In: Flora of China. Vol. 24. Flagellariaceae through Marantaceae (Zh. Wu \& P. H. Raven, eds.), pp. 165-202, Science Press, Beijing \& Missouri Botanical Garden Press, St. Louis.

Yang, L., J.-M. Xu, X.-L. Zhang \& H.-Q. Wan 1998. Karyological studies of six species of the genus Allium. Acta Phytotaxonomica Sinica 36(1):36-46.

Zakharieva, O. I. \& L. M. Makushenko 1969. Chromosome numbers of monocotyledons from the families Liliaceae, Iridaceae, Amaryllidaceae and Araceae. Botanicheskii Zhurnal 54(8): 12131227 (in Russian). [Захарьева О.И., Макушенко А.М. 1969. Хромосомные числа оАнодольных растений из семейств Liliaceae, Iridaceae, Amaryllidaceae и Araceae // Бот. журн. T. 54, № 8. C. 1213-1227.]

Zhang, Y.-X. 1994. Studies on chromosomes of some plants from Guandi Mountain, Shanxi. Journal of Wuhan Botanical Research 12(2):201-206.

Zi, D. S. 1995. Genus Tournefortia L. In: Flora of China. Vol. 16. Gentianaceae through Boraginaceae (Zh. Wu \& P. H. Raven, eds.), pp. 341-342, Science Press, Beijing \& Missouri Botanical Garden Press, St. Louis. 
